\title{
Fæðuval og næring kvenna á meðgöngu með tilliti til líkamspyngdar
}

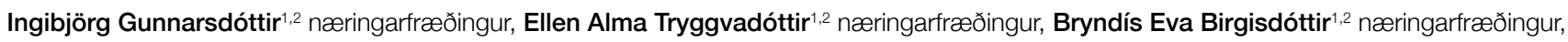

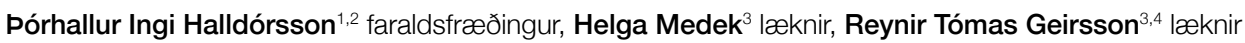

\section{ÁGRIP}

Tilgangur: Næringarástand fyrir og á meðgöngu getur haft áhrif á proska vöxt og heilsu barnsins til skemmri og lengri tíma. Markmið rannsóknarinnar var að rannsaka næringargildi fæðu hjá barnshafandi konum á höfuð̋borgarsvæðinu og að kanna hvort mataræði kvenna í kjörpyngd fyrir pungun væri frábrugðið pví sem er hjá konum sem voru yfir kjörpyngd. Efniviður/aðferðir: Pátttakendur voru konur á aldrinum 18-40 ára ( $n=183$ ), sem höfðu búsetu á höfuðborgarsvæðinu. Mataræði var kannað með fjögurra daga vigtaðri skráningu í 19.-24. viku meðgöngu ( $n=98$ með líkamspyngdarstuðull (LPS) $\left.<25 \mathrm{~kg} / \mathrm{m}^{2}\right) ; \mathrm{n}=46$ með LPS $25-29,9 \mathrm{~kg} / \mathrm{m}^{2}$ og $\mathrm{n}=39$ með LPS $\geq 30 \mathrm{~kg} / \mathrm{m}^{2}$ ).

Niðurstöður: Einungis 20\% kvennanna náđu lágmarksviðmiðum trefjaneyslu sem eru $25 \mathrm{~g}$ á dag. Viðbættur sykur veitti að jafnaði 12\% (SF $\pm 5 \%)$ af heildarorku fæðisins. Um fjórðungur kvennanna gæti hafa átt á hættu að fullnægja ekki pörf fyrir joð, D-vítamín og DHA (dókósahexensýru ). Ofneysla vítamína og steinefna (úr fæði og bætiefnum) sást ekki. Miððgildi neyslu á mjólk og mjólkurvörum ( 346 g/dag miðað̃ við 258 g/dag, $\mathrm{p}<0,05)$, gos- og svaladrykkjum (200 g/dag miðað við $122 \mathrm{~g} / \mathrm{dag}, \mathrm{p}<0,05)$ og kartöfluflögum og poppi (13 g/dag miðað við $0 \mathrm{~g} / \mathrm{dag}, \mathrm{p}<0,05)$ var hærra meðal kvenna með LPS $\geq 30 \mathrm{~kg} / \mathrm{m}^{2}$ fyrir pungun heldur en kvenna sem voru i kjörpyngd fyrir pungun.

Ályktanir: Huga parf betur að fæðuvali kvenna fyrir og á meðgöngu, ekki síst meðal kvenna yfir kjörpyngd. Hluti barnshafandi kvenna fullnægir ekki pörf fyrir næringarefni á borð við joð, D-vítamín og DHA, sem öll gegna lykilhlutverki við fósturproska.

Fyrirspurnir: Ingibjörg Gunnarsdóttir, ingigun@hi.is

\section{Inngangur}

${ }^{1}$ Rannsóknastofu í næringarfræđi viơ Landspítala og Háskóla Íslands, ${ }^{2}$ matvæla- og næringarfræðideild, heilbrigðisvísindasvið

Háskóla Íslands, ${ }^{3}$ kvennadeild, kvenna- og barnasviði Landspítala ${ }^{4}$ ææknadeild Háskóla Islands.

Rannsóknir síðastliðinna 20 ára, bæði meðal manna og dýra, benda til pess að umhverfi fósturs í móðurkviði geti haft umtalsverð áhrif á heilsu afkvæmisins allt fram á fullorðinsár. ${ }^{1}$ Næringarástand fyrir og á meðgöngu getur ekki aðeins haft áhrif á heilsu móðurinnar heldur einnig á proska, vöxt og heilsu barnsins til skemmri og lengri tíma. ${ }^{2-4}$

Mataræði mismunandi samfélagshópa hefur verið rannsakað hérlendis undanfarin ár. ${ }^{5,6}$ Pekkingin hefur meðal annars nýst við stefnumótun í lýðheilsumálum. Mataræði barnshafandi kvenna hefur verið rannsakað prisvar sinnum síðastliðin 15 ár.-9 Tíðnispurningalisti var notaður til að kanna mataræði í öllum pessum rannsóknum. Prátt fyrir að reynslan af notkun slíks spurningalista sé góð í stórum faraldsfræðilegum rannsóknum par sem ætlunin er að flokka einstaklinga í hópa eftir fæðuvali og tengja við heilsufarspætti ${ }^{10-13}$ hentar pessi aðferðafræði illa ef markmiðið er að magngreina neyslu matvæla og einstakra næringarefna. Nákvæmar upplýsingar um neyslu matvælategunda eru meðal annars mikilvægar við að meta hættu á of mikilli eða lítilli neyslu næringarefna miðað við ráðleggingar. ${ }^{14}$

Markmið rannsóknarinnar var að kanna fæðuval
Undirmarkmið rannsóknarinnar var að kanna hvort mataræði kvenna í kjörpyngd fyrir meðgöngu væri frábrugðið mataræði kvenna sem voru of pungar eða of feitar fyrir meðgöngu.

\section{Efniviður og aðferðir}

Pátttakendur voru íslenskar konur á aldrinum 18-40 ára með búsetu á höfuðborgarsvæðinu. Gagnanna var aflað í rannsókninni Göngum dálítið meira (GDM) sem fór fram á kvennadeild Landspítala í samstarfi við Rannsóknastofu í næringarfræði frá apríl 2012 fram í október 2013. ${ }^{15}$ Konum var boðin pátttaka í rannsókninni við 20 vikna ómskoðun á fósturgreiningadeild kvennadeildar Landspítala. Upphafleg pátttökuskilyrði voru auk búsetu og aldurs, reykleysi á meðgöngu, engin fjölskyldusaga um sykursýki eða meðgöngusykursýki, fyrsta til priðja meðganga og líkamspyngdarstuðull (LPS) á bilinu $18,5-24,9 \mathrm{~kg} / \mathrm{m}^{2}$ (kjörpyngd) eða LPS 30-<40 kg/m² (offita). Markmiðið var að skrá að minnsta kosti 100 konur í kjörpyngd og 100 konur með LPS $30-<40 \mathrm{~kg} / \mathrm{m}^{2}$ til pátttöku. Sex mánuðum eftir upphaf rannsóknar var ákveðið að bjóða til pátttöku konum sem flokkast í ofpyngd (LPS $\left.25-29,9 \mathrm{~kg} / \mathrm{m}^{2}\right)$, par sem hægt gekk að skrá konur með LPS $30-<40 \mathrm{~kg} / \mathrm{m}^{2}$ sem fullnægðu skilyrðum um pátttöku. Í heildina var leitað eftir sampykki 273 kvenna, par af neituðu 56 (kjörpyngd n=43; ofpyngd $n=1$; offita $n=12$ ) pátttöku, auk pess sem 34 konur skiluðu ekki matardagbókum. Pví voru niðurstöður fyrir 183 konur (67\%) sem 
Tafla I. Aldur, hæð, pyngd fyrir meðgöngu, pyngdaraukning og meðgöngulengd við pátttöku, skipt eftir likamspyngdarstuðli (LPS) fyrir meðgöngu (kjörpyngd; LPS <25 $\mathrm{kg} / \mathrm{m}^{2}$, ofpyngd; LPS 25-29,9 kg/m² og offitu; LPS $\geq 30 \mathrm{~kg} / \mathrm{m}^{2}$ ). Niðurstöður eru birtar sem meðaltöl og staðalfrávik (SF).

\begin{tabular}{|c|c|c|c|c|c|c|c|c|c|}
\hline & \multicolumn{3}{|c|}{$\begin{array}{c}\text { Kjörpyngd } \\
n=98\end{array}$} & \multicolumn{3}{|c|}{$\begin{array}{c}\text { Ofpyngd } \\
n=46\end{array}$} & \multicolumn{3}{|c|}{$\begin{array}{l}\text { Offita } \\
n=39\end{array}$} \\
\hline & Meðaltal & & SF & Meðaltal & & SF & Meðaltal & & SF \\
\hline Aldur (ár) & 28,0 & \pm & 4,9 & 30,0 & \pm & 4,3 & 30,1 & \pm & 4,6 \\
\hline Нæð (cm) & 168 & \pm & 5,6 & 167 & \pm & 5,6 & 168 & \pm & 6,0 \\
\hline Meðgöngulengd við pátttöku (dagar) & 142 & \pm & 3,0 & 147 & \pm & 6,7 & 145 & \pm & 3,7 \\
\hline Pyngd fyrir meðgöngu (kg) & 60,8 & \pm & 6,3 & 76 & \pm & 5,3 & 93,6 & \pm & 9,7 \\
\hline Pyngd við pátttöku $(\mathrm{kg})^{\star}$ & 65,7 & \pm & 6,8 & 81,4 & \pm & 7,1 & 97,3 & \pm & 10,4 \\
\hline Pyngdaraukning við pátttöku (kg)* & 4,7 & \pm & 2,6 & 5,3 & \pm & 4,1 & 3,2 & \pm & 4,9 \\
\hline LPS fyrir meðgöngu $\left(\mathrm{kg} / \mathrm{m}^{2}\right)^{\star}$ & 21,5 & \pm & 1,6 & 27,2 & \pm & 1,2 & 33,2 & \pm & 2,6 \\
\hline LPS við pátttöku $\left(\mathrm{kg} / \mathrm{m}^{2}\right)^{\star}$ & 23,2 & \pm & 1,8 & 29,2 & \pm & 1,7 & 34,0 & \pm & 2,3 \\
\hline
\end{tabular}

*Upplýsingar um pyngd við pátttöku vantaði fyrir 14 pátttakendur í kjörpyngd, einn í ofpyngd og sjö of feita.

unnt var að nota. Konurnar skrifuðu undir sampykkisyfirlýsingu vegna pátttöku í rannsókninni. Siðanefnd Landspítala sampykkti rannsóknaráætlunina (58/2011).

Allur matur og drykkur sem konurnar neyttu var vigtaður með \pm 1 g nákvæmni (PHILIPS HR 2385 vigt, Ungverjalandi) í fjóra daga samfellt á 19.-24. viku meðgöngu, annaðhvort frá miðvikudegi til laugardags eða frá laugardegi til priðjudags. Neysla matar, drykkjar og allra fæðubótarefna var skráð í matardagbók jafnóðum. Konunum var úthlutað fæðuvigt og pær fengu bæði skriflegar og munnlegar leiðbeiningar varðandi útfyllingu matardagbóka. Til að auka nákvæmni í úrvinnslu var lögð rík áhersla á að skráðar væru upplýsingar um tegund matvæla sem neytt var (vörumerki) og eftir atvikum uppskriftir ef um heimalagaðan mat var að ræða.

Niðurstöður voru færðar inn í næringarútreikningaforritið ICEFOOD 2.0 sem hannað var fyrir Landskönnun á mataræði Íslendinga 2002 (útgáfa 1.0) og endurbætt fyrir Landskönnun á mataræði Íslendinga 2010-2011. ${ }^{5}$ ICEFOOD styðst annars vegar við íslenska gagnagrunninn um efnainnihald matvæla, ÍSGEM, og hins vegar gagnagrunn fyrrum Lýðheilsustöðvar (nú innan Embættis landlæknis) um samsetningu algengra rétta og skyndibita á íslenskum markaði. Tekið var tillit til rýrnunar næringarefna við eldun. Gagnagrunnurinn hefur að geyma 607 uppskriftir og rétti. Birtar eru niðurstöður um neyslu valinna fæðutegunda (í grömmum á dag (g/dag)), orku (sem kkal/dag), orkugefandi næringarefna (í g/ dag og sem hlutfall af heildarorkuneyslu), auk neyslu vítamína og steinefna. Niðurstöðurnar voru bornar saman við ráðleggingar um fæðuval og ráðlagða dagskammta (RDS) næringarefna fyrir barnshafandi konur. ${ }^{14,16}$ RDS er skilgreindur sem pað magn næringarefnis sem fullnægir pörf nánast allra í pýðinu (meðalpörf + tvö staðalfrávik). Eins voru niðurstöður bornar saman við áætlaða meðalpörf fyrir næringarefni, sem pó eru einungis til fyrir konur sem ekki eru barnshafandi. ${ }^{14}$ Ef einstaklingur neytir minna en sem nemur meðalpörf fyrir viðkomandi næringarefni má áætla að 50\% líkur séu á að viðkomandi fullnægi ekki pörf sinni fyrir næringarefnið. Að auki voru niðurstöðurnar bornar saman við gildi sem sett hafa verið fram um efri mörk hættulausrar neyslu fyrir ákveðin næringarefni. ${ }^{14,16}$

Konurnar veittu upplýsingar um aldur, áætlaðan fæðingardag, hæð og líkamspyngd fyrir meðgöngu, en voru vigtaðar við eða stuttu eftir komu í 20 vikna ómskoðunina (19.-24. viku meðgöngu).
T-próf var notað til að kanna hugsanlegan mun á normaldreifðum breytum á borð við neyslu næringarefna og pyngdaraukningu milli kvenna í kjörpyngd og offitu annars vegar og milli kjörpyngdar og of pyngdar hins vegar. Neysla matvæla er sjaldnast normaldreifð og pví var stuðst við Mann-Whitney U-próf par sem við átti. Marktækni var skilgreind sem $p<0,05$.

\section{Niðurstöður}

Upplýsingar um aldur, hæð, líkamspyngd og líkamspyngdarstuðul fyrir meðgöngu, áætlaða meðgöngulengd, sem og líkamspyngdarstuðul og heildarpyngdaraukningu má sjá í töflu I. Við 20. viku meðgöngu höfðu konur í kjörbyngd pyngst að jafnaði $1,5 \mathrm{~kg}$ meira en konur með LPS $\geq 30 \mathrm{~kg} / \mathrm{m}^{2}$ ( $\left.\mathrm{p}=0,04\right)$. Pyngdaraukning kvenna sem flokkuðust í of pyngd fyrir pungun virtist einnig meiri heldur en kvenna með LPS $\geq 30 \mathrm{~kg} / \mathrm{m}^{2}$, en meiri dreifing (stærra SF) pyngdaraukningar í flokki of pungra kvenna leiddi til pess að munurinn var ekki tölfræðilega marktækur.

Heildarorka fæðunnar var að meðaltali 2149 kkal \pm 447 kkal/ dag (tafla II). Hvorki reyndist marktækur munur í orkuneyslu né hlutfallslegri skiptingu orkuefnanna milli kvenna sem voru í kjörpyngd fyrir pungun $(2157 \pm 405 \mathrm{kkal} / \mathrm{dag})$ og peirra sem voru of pungar (2092 $\pm 457 \mathrm{kkal} / \mathrm{dag})$ eða flokkuðust sem of feitar $(2195 \pm 533$ kkal/dag) fyrir pungun. Ekki reyndist heldur munur á neyslu einstakra vítamína eða steinefna milli pyngdarhópa. Niðurstöður eru par af leiðandi birtar sem meðaltöl og staðalfrávik fyrir allar konurnar saman, ásamt dreifingu neyslunnar (hundraðshlutar).

Í heildina var mataræði langstærsta hluta kvennanna innan ráðlegginga um hlutfall heildarorku hvað varðar prótein, heildarfitu og kolvetni. Hins vegar var hlutfall mettaðra fitusýra að meðaltali hærra ( $14 \%$ af heildarorku) heldur en mælt er með (tafla II). Neysla á dókósahexensýru (DHA) var að meðaltali 293 mg á dag. Pegar dreifing neyslunnar var skoðuð sást að einungis um $35 \%$ kvennanna náði markmiðum um neyslu $\geq 200$ mg af DHA daglega.

Gæði kolvetna í fæði kvennanna töldust lítil, sem endurspeglaðist í lítilli trefjaneyslu (аð meðaltali 2,1 g/MJ eða um pað bil $18 \mathrm{~g} / \mathrm{dag})$ og mikilli neyslu á viðbættum sykri (12\% af heildarorku) miðað við ráðleggingar (tafla II). Einungis 20\% pátttakenda náði lágmarksviðmiðum trefjaneyslu (25 g/dag). Rúmlega 60\% 
Tafla II. Orka og orkuefandi næringarefni i fæði pátttakenda ásamt ráðlagðri neyslu samkvæmt norrænum og íslenskum ráðleggingum. ${ }^{14,15}$ Niðurstöður eru birtar sem meðaltal, staðalfrávik (SF) og hundraðshlutar.

\begin{tabular}{|c|c|c|c|c|c|c|c|c|}
\hline & \multirow[t]{2}{*}{ Ráđlegging \% } & \multirow{2}{*}{$\begin{array}{c}\text { Meðaltal } \\
n=183\end{array}$} & \multirow[t]{2}{*}{ SF } & \multicolumn{5}{|c|}{ Hundraðshlutar } \\
\hline & & & & 5 & 25 & 50 & 75 & 95 \\
\hline Orka kcal & & 2149 & 447 & 1414 & 1838 & 2143 & 2399 & 2967 \\
\hline Prótein E\% & $10-20$ & 16 & 2 & 12 & 14 & 16 & 17 & 20 \\
\hline Fita E\% & $25-40$ & 35 & 5 & 28 & 31 & 34 & 38 & 43 \\
\hline Mettaðar fitusýrur E\% & $<10$ & 14 & 2 & 10 & 12 & 14 & 15 & 18 \\
\hline Einómettaðar fitusýrur E\% & $10-20$ & 11 & 2 & 8 & 10 & 11 & 12 & 15 \\
\hline Fjölómettaðar fiturýrur E\% & $5-10$ & 6 & 2 & 3 & 4 & 6 & 7 & 9 \\
\hline Lífsnauðsynlegar fitusýrur E\% & $\geq 5$ & 12 & 4 & 6 & 9 & 12 & 15 & 20 \\
\hline n-3 fitursýrur (heild) ${ }^{\star \star} \mathrm{E} \%$ & 1 & 2,7 & 1,5 & 1,1 & 1,7 & 2,3 & 3,1 & 5,5 \\
\hline Langar $n-3$ fitusýrur ${ }^{\star \star \star} E \%$ & - & 0,2 & 0,3 & 0,0 & 0,1 & 0,1 & 0,3 & 0,9 \\
\hline DHA (C22:6. n-3) mg & $200 \mathrm{mg} / \mathrm{dag}$ & 293 & 370 & 28 & 63 & 123 & 378 & 1160 \\
\hline Transfitusýrur E\% & eins lágt og mögulegt er & 0,7 & 0,2 & 0,4 & 0,5 & 0,7 & 0,8 & 1,1 \\
\hline Kolvetni E\% & $45-60$ & 48 & 5 & 39 & 44 & 48 & 52 & 55 \\
\hline Viðbættur sykur E\% & $<10$ & 12 & 5 & 5 & 9 & 11 & 15 & 21 \\
\hline Trefjar g/MJ & $3 \mathrm{~g} / \mathrm{MJ}$ & 2,1 & 0,6 & 1,3 & 1,7 & 2,1 & 2,5 & 3,3 \\
\hline
\end{tabular}

${ }^{*} \mathrm{C} 18: 2 \mathrm{n}-6$ and $\mathrm{C} 18: 3 \mathrm{n}-3$

** $C 18: 3 n-3, C 18: 4 n-3, C 20: 3 n-3, C 20: 4 n-3, C 20: 5 n-3, C 22: 3 n-3, C 22: 5 n-3, C 22: 6 n-3$

${ }^{* *} \mathrm{C} 20: 3 \mathrm{n}-3, \mathrm{C} 2 \mathrm{O}: 4 \mathrm{n}-3, \mathrm{C} 20: 5 \mathrm{n}-3, \mathrm{C} 22: 3 \mathrm{n}-3, \mathrm{C} 22: 5 \mathrm{n}-3, \mathrm{C} 22: 6 \mathrm{n}-3$

kvennanna neyttu meira en sem svarar $50 \mathrm{~g}$ af viðbættum sykri á dag, sem í praktískum tilgangi er notað sem viðmið um efri mörk neyslu á viðbættum sykri (samsvarar 10\% af heildarorku miðað við 2000 hitaeininga fæði). Um 15\% kvennanna borðaði að meðaltali meira en $100 \mathrm{~g}$ af viðbættum sykri á dag (sem samsvarar rúmlega einum desilítra).

Í töflu III má sjá heildarneyslu vítamína og steinefna sem fengust úr mat og bætiefnum. Meðalneysla vítamína og steinefna var almennt meiri en RDS fyrir viðkomandi næringarefni. Hins vegar gæti að minnsta kosti fjórðungur kvennanna átt á hættu að fullnægja ekki pörf sinni fyrir D-vítamín, joð og fólat (metið sem minni neysla en áætluð meðalpörf). Hætta á ofneyslu vítamína og steinefna (úr fæði og bætiefnum) virtist ekki vera til staðar í pýðinu.

Tafla IV sýnir meðalneyslu valinna fæðutegunda og matvæla úr mismunandi fæðuflokkum. Einungis fjórðungur náði markmiðum um neyslu sem svarar $200 \mathrm{~g}$ af ávöxtum á dag og $36 \%$ borðuðu minna en sem svarar einum ávexti á dag (100 g). Innan við $10 \%$ náði markmiðum um neyslu að minnsta kosti $200 \mathrm{~g}$ af grænmeti á dag og tæplega 40\% neyttu sem svarar 100 g af grænmeti á dag að jafnaði. Neysla á baunum, ertum, hnetum og fræjum mældist mjög lág og aðeins lítill hluti virtist neyta pessara vara. Ef miðað er við að hver fiskmáltíð sé um pað bil $150 \mathrm{~g}$ benda niðurstöðurnar til pess að konurnar hafi borðað fisk rúmlega einu sinni í viku að jafnaði (meðalneysla 29 $\pm 29 \mathrm{~g} / \mathrm{dag}$ ), en ráðlagt er að fiskur sé á borðum að minnsta kosti tvisvar sinnum í viku (sem samsvarar rúmlega $40 \mathrm{~g} / \mathrm{dag}$ að jafnaði). Rúmlega fjórðungur drakk meira en sem nemur stóru glasi af gos- og svaladrykkjum daglega (300 ml).

Miðgildi neyslu á mjólk og mjólkurvörum (346 g/dag miðað við $258 \mathrm{~g} / \mathrm{dag}, \mathrm{p}<0,05)$, gos- og svaladrykkjum (200 g/dag miðað við $122 \mathrm{~g} / \mathrm{dag}, \mathrm{p}<0,05)$ og kartöfluflögum og poppi (13 g/dag miðað við
0 g/dag, p<0,05) var hærra meðal kvenna með LPS $\geq 30$ kg/m² fyrir pungun heldur en kvenna sem voru í kjörpyngd fyrir pungun. Ekki reyndist marktækur munur á fæðuvali kvenna sem flokkuðust í ofpyngd miðað við konur í kjörpyngd.

\section{Umræða}

Niðurstöður rannsóknarinnar benda til pess að töluverð tækifæri ættu að vera til að bæta mataræði pungaðra kvenna og kvenna á barneignaraldri. Hluti barnshafandi kvenna virtist ekki fullnægja pörf fyrir næringarefni á borð við joð, D-vítamín og DHA, sem öll gegna lykilhlutverki við fósturproska. ${ }^{17-20}$ Lítil gæði heildarmataræðis hér á landi eru í samræmi við niðurstöður erlendra rannsókna. ${ }^{21-22}$ Hins vegar virtist hætta á ofneyslu vítamína og steinefna ekki vera til staðar miðað við pá neyslu fæðu og fæðubótarefna sem skráð var í matardagbækurnar. Í rannsókninni reyndist almennt ekki vera mikill munur á mataræði kvenna sem voru í kjörpyngd og peirra sem voru of feitar áður en pær urðu barnshafandi. Hins vegar benda niðurstöðurnar til pess að konur í kjörpyngd fyrir meðgöngu neyti ívið minna af óhollum fæðutegundum á borð við gos- og svaladrykki og snakk.

Áður birtar niðurstöður norsku MoBa (Norwegian Mother and Child Cohort Study; n 87.000) og dönsku DNBC (Danish National Birth Cohort; $\mathrm{n} 70.000$ ) rannsóknanna benda til að fæðumynstur kvenna á meðgöngu, sem einkennist af ríflegri neyslu ávaxta og grænmetis, fisks og hollrar fitu en um leið minni neyslu á næringarsnauðum fæðutegundum, tengist minni líkum á meðgöngueitrun, fyrirburafæðingum og öðrum meðgöngukvillum. ${ }^{11-13,23,24}$ Fyrri greiningar gagna í rannsókn okkar sýndu að heilsusamlegt mataræði kvenna á meðgöngu tengist minni líkum á meðgöngusykursýki, eftir að leiðrétt hafði verið fyrir páttum á borð við aldur, fjölda fyrri barna, pyngd fyrir meðgöngu, orkuinntöku á með- 
Tafla III. Ráđlagður dagskammtur (RDS) fyrir barnshafandi konur, ${ }^{14,15}$ áætluð međalpörf kvenna á barneignaraldri' ${ }^{14}$, efri mörk hættulausrar neys/u ${ }^{14}$ ásamt upplýsingum um magn vítamína og steinefna í fæði pátttakenda (par með töldum bætiefnum). Niðurstöður eru birtar sem meðaltal, staðalfrávik (SF) og hundraðshlutar.

\begin{tabular}{|c|c|c|c|c|c|c|c|c|c|c|}
\hline & \multirow[t]{2}{*}{ RDS } & \multirow[t]{2}{*}{ Meðalpörf } & \multirow[t]{2}{*}{ Efri mörk } & \multirow{2}{*}{$\begin{array}{c}\text { Meðaltal } \\
n=183\end{array}$} & \multirow[t]{2}{*}{ SF } & \multicolumn{5}{|c|}{ Hundraðshlutar } \\
\hline & & & & & & 5 & 25 & 50 & 75 & 95 \\
\hline A-vítamín, RJ ( $\mu \mathrm{g})$ & 800 & 500 & - & 1088 & 690 & 377 & 599 & 835 & 1369 & 2599 \\
\hline Retinól $(\mu \mathrm{g})$ & - & - & 3000 & 890 & 661 & 214 & 421 & 627 & 1204 & 2338 \\
\hline$\beta$-karótín $(\mu \mathrm{g})$ & - & - & - & 2227 & 2096 & 366 & 826 & 1591 & 2949 & 6069 \\
\hline D-vítamín $(\mu \mathrm{g})$ & 15 & 7,5 & 100 & 13,1 & 11,3 & 1,7 & 4,2 & 10,8 & 18,0 & 32,9 \\
\hline E-vítamín, a-TJ (mg) & 10 & 5 & $300^{*}$ & 15,2 & 8,7 & 5,1 & 8,6 & 14,0 & 19,0 & 32,6 \\
\hline B1-vítamín, píamín (mg) & 1,5 & 0,9 & - & 2,1 & 1,2 & 0,8 & 1,3 & 1,8 & 2,5 & 4,4 \\
\hline B2-vítamín, ríbóflavín (mg) & 1,6 & 1,1 & - & 2,6 & 1,3 & 1,1 & 1,6 & 2,3 & 3,2 & 5,6 \\
\hline Níasín-jafngildi (mg) & 17 & 12 & - & 40 & 15 & 22 & 29 & 37 & 47 & 71 \\
\hline B6-vítamín (mg) & 1,4 & 1,1 & $25^{\star}$ & 2,8 & 1,6 & 1,1 & 1,6 & 2,3 & 3,4 & 5,9 \\
\hline Fólat, alls $(\mu \mathrm{g})$ & 500 & 200 & $1000^{*}$ & 580 & 322 & 208 & 324 & 527 & 738 & 1211 \\
\hline B12-vítamín ( $\mu \mathrm{g})$ & 2 & 1,4 & - & 6,4 & 2,8 & 2,9 & 4,5 & 5,7 & 7,7 & 12,3 \\
\hline C-vítamín (mg) & 85 & 50 & 1000 & 162 & 125 & 51 & 95 & 135 & 204 & 318 \\
\hline Kalk (mg) & 900 & 500 & 2500 & 1107 & 366 & 590 & 878 & 1063 & 1276 & 1702 \\
\hline Fosfór (mg) & 700 & 450 & 3000 & 1531 & 346 & 1047 & 1278 & 1517 & 1723 & 2153 \\
\hline Magnesíum (mg) & 280 & & - & 308 & 81 & 192 & 246 & 300 & 361 & 452 \\
\hline Natríum (mg) & - & - & $2400^{\star \star *}$ & 2838 & 681 & 1776 & 2341 & 2790 & 3200 & 3989 \\
\hline Kalíum (mg) & 3100 & - & 3700 & 2754 & 679 & 1796 & 2239 & 2654 & 3161 & 3956 \\
\hline Járn (mg) & $15^{\star \star}$ & 10 & - & 20 & 21 & 6 & 10 & 15 & 22 & 40 \\
\hline Sink (mg) & 9 & 5 & 25 & 17 & 10 & 7 & 10 & 14 & 23 & 38 \\
\hline Kopar (mg) & 1 & 0,7 & 5 & 2,0 & 1,3 & 0,8 & 1,1 & 1,5 & 2,8 & 5,0 \\
\hline J০ð $(\mu \mathrm{g})$ & 175 & 100 & 600 & 186 & 120 & 65 & 94 & 152 & 240 & 404 \\
\hline Mangan (mg) & - & - & - & 4,4 & 2,0 & 1,9 & 2,8 & 4,0 & 5,3 & 8,7 \\
\hline Króm $(\mu \mathrm{g})$ & - & - & - & 48 & 33 & 17 & 25 & 38 & 67 & 120 \\
\hline Selen $(\mu \mathrm{g})$ & 60 & 30 & 300 & 84 & 37 & 41 & 59 & 75 & 104 & 168 \\
\hline Molýbden ( $\mu \mathrm{g})$ & - & - & - & 80 & 78 & 15 & 25 & 38 & 136 & 260 \\
\hline
\end{tabular}

* Á einungis við magn sem neytt er í formi fæðubótarefna.

* * Járnpörf er mjög breytileg međal barnshafandi kvenna. Pörfin fer eftir stöðu járnbirgða við upphaf meðgöngu.

*** Markmiðið er að meðal natríumneysla pýðis fari ekki yfir $2400 \mathrm{mg} / \mathrm{dag}$.

göngu, vikulegri pyngdaraukningu og hreyfingu (OR: 0,36 95\% CI: $0,14,0,94){ }^{15}$

Kenningar breska vísindamannsins David Barkers ${ }^{1}$ um að umhverfi fósturs í móðurkviði geti haft áhrif á vöxt, proska og heilsu barns allt fram á fullorðinsár voru umdeildar framan af. Rannsóknir síðastliðinna áratuga hafa slegið á raddir um að pað skipti ekki máli hvað kona borðar á meðgöngu og pær staðhæfingar heyrast vart lengur. Ný pekking á pó enn eftir að skila sér inn í klínískt starf, bæði hérlendis sem og erlendis. Í klínískum leiðbeiningum um meðgönguvernd heilbrigðra kvenna í eðlilegri meðgöngu ${ }^{25}$ er að mjög takmörkuðu leyti fjallað um fæðuval. Barnshafandi konum er bent á bækling um mataræði á meðgöngu sem gefinn var út árið $2008^{26}$ en pekking hefur aukist umtalsvert frá pessum tíma. Endurskoðun ráðlegginganna er aðkallandi. Einnig er vel pekkt að pyngd móður fyrir pungun, ásamt mikilli pyngdaraukningu á meðgöngu, tengist ýmsum kvillum á meðgöngu og aukinni tíðni ofpyngdar hjá barninu. ${ }^{27,28}$ Líkamspyngdarstuðull er víða notaður til að meta pörf fyrir lífsstílsíhlutanir á meðgöngu, pað er að segja aðgerðir sem fela í sér bætt mataræði og aukna hreyfingu sem geta skilað árangri sem er mælanlegur á formi minni pyngdaraukn- ingar á meðgöngu. ${ }^{29,30}$ Hins vegar eru verndandi áhrif lífsstílsíhlutana með tilliti til hættu á meðgöngusykursýki ekki eins skýr. ${ }^{31}$

Nýlega voru birtar niðurstöður úr einni stærstu íhlutunarrannsókn ( $\mathrm{n}=1555)$ sem hefur verið framkvæmd meðal barnshafandi kvenna. ${ }^{32}$ Pær bentu ekki til að unnt væri að beita lífsstílsíhlutun til að minnka líkur á meðgöngusykursýki og pungburafæðingum. Hluti skýringarinnar gæti pó hafa legið í pví að konur í rannsókninni, ${ }^{32}$ líkt og í öðrum svipuðum rannsóknum á pessu sviði, ${ }^{29}$ voru valdar inn til pátttöku á grundvelli pyngdar fyrir pungun, en ekki á grundvelli pess hvernig mataræði peirra (eða hreyfing) var í upphafi meðgöngu. Gert var ráð fyrir að allar konur yfir kjörpyngd hefðu gagn af pví að breyta mataræði sínu. Til að setja petta í annað samhengi mætti líkja vali pátttakenda við að ný meðferð við háprýstingi (til dæmis lyf) væri prófuð í hópi par sem einungis helmingur pátttakenda væri með háprýsting. Ein áhugaverðasta niðurstaða rannsóknar okkar, sem birt var á síðasta ári, var að konur yfir kjörpyngd sem borðuðu hollan mat reyndust ekki vera í meiri hættu á að fá meðgöngusykursýki heldur en konur í kjörpyngd..$^{15}$ Petta bendir til pess að nauðsynlegt geti verið að velja pungaðar konur inn í lífsstílsíhlutanir eftir niðurstöðum skimun- 
Tafla IV. Neysla algengra matvæla og fæðu úr völdum matvælaflokkum (grömm á dag). Niðurstöður eru birtar sem meðaltal, staðalfrávik (SF) og hundraðshlutar.

\begin{tabular}{|c|c|c|c|c|c|c|c|}
\hline \multicolumn{8}{|l|}{ Yfirflokkar } \\
\hline \multirow[t]{2}{*}{ Undirflokkar } & \multirow{2}{*}{$\begin{array}{c}\text { Meðaltal } \\
n=183\end{array}$} & \multirow[t]{2}{*}{ SF } & \multicolumn{5}{|c|}{ Hundraðshlutar } \\
\hline & & & 5 & 25 & 50 & 75 & 95 \\
\hline Mjólk, mjólkurvörur, alls & 312 & 185 & 55 & 183 & 275 & 413 & 690 \\
\hline Drykkjarmjólk & 210 & 168 & 11 & 80 & 180 & 296 & 559 \\
\hline Sýrðar mjólkurvörur & 100 & 90 & 0 & 25 & 85 & 152 & 296 \\
\hline Ostar & 44 & 25 & 15 & 26 & 40 & 55 & 92 \\
\hline ís & 19 & 32 & 0 & 0 & 0 & 30 & 85 \\
\hline Kornmatur, brauð̃ og kökur, alls & 270 & 96 & 135 & 200 & 260 & 323 & 414 \\
\hline Ómalað og heilmalað korn. Hrísgrjón, maís og hafragrjón & 22 & 28 & 0 & 0 & 10 & 36 & 73 \\
\hline Mjöl & 16 & 18 & 0 & 1 & 10 & 28 & 54 \\
\hline Morgunverðarkorn, hafragrautur & 50 & 53 & 0 & 13 & 38 & 72 & 161 \\
\hline Brauð, hrökkbrauð, tvíbökur, bruður, skonsur & 103 & 43 & 46 & 70 & 101 & 129 & 178 \\
\hline Kex, sætt, ósætt, smákökur & 11 & 17 & 0 & 0 & 4 & 16 & 48 \\
\hline Kökur, tertur, ostakökur, kleinur & 49 & 46 & 0 & 19 & 38 & 65 & 150 \\
\hline Pasta, núðlur, kús-kús & 20 & 33 & 0 & 0 & 0 & 30 & 90 \\
\hline Grænmeti og kartöflur, alls & 146 & 76 & 48 & 90 & 132 & 182 & 291 \\
\hline Nýir, frystir rótarávextir nema kartöflur & 25 & 24 & 3 & 8 & 16 & 32 & 69 \\
\hline Nýtt, fryst grænmeti: stönglar, blöð, aldin & 67 & 54 & 5 & 30 & 56 & 89 & 184 \\
\hline Kartöflur & 23 & 27 & 0 & 0 & 15 & 37 & 76 \\
\hline Baunir, ertur & 5 & 14 & 0 & 0 & 0 & 4 & 22 \\
\hline Nýir sveppir & 4 & 6 & 0 & 0 & 0 & 6 & 15 \\
\hline Niðursoðið og niðurlagt grænmeti, tómatmauk & 9 & 13 & 0 & 0 & 2 & 14 & 34 \\
\hline Franskar kartöflur & 12 & 19 & 0 & 0 & 0 & 20 & 52 \\
\hline Ávextir, ber, hnetur og fræ, alls & 166 & 116 & 10 & 78 & 141 & 229 & 397 \\
\hline Nýir, frystir ávextir & 134 & 107 & 0 & 55 & 110 & 194 & 336 \\
\hline Ný, fryst ber & 19 & 36 & 0 & 0 & 0 & 26 & 83 \\
\hline Hnetur, fræ & 5 & 12 & 0 & 0 & 0 & 4 & 25 \\
\hline Niðursoðnir ávextir, ber, ávaxtagrautar, ávaxtamauk & 1 & 3 & 0 & 0 & 0 & 0 & 7 \\
\hline Purrkaðir ávextir og ber & 4 & 8 & 0 & 0 & 0 & 4 & 20 \\
\hline Sultur & 2 & 4 & 0 & 0 & 0 & 3 & 10 \\
\hline Kjöt og kjötvörur alls & 55 & 36 & 3 & 26 & 49 & 77 & 119 \\
\hline Lambakjöt, kindakjöt & 11 & 19 & 0 & 0 & 0 & 20 & 50 \\
\hline Nautakjöt & 16 & 20 & 0 & 0 & 12 & 24 & 60 \\
\hline Svínakjöt & 6 & 13 & 0 & 0 & 0 & 5 & 36 \\
\hline Fars, farsvörur, pylsur, bjúgu, áleggspylsur & 19 & 19 & 0 & 4 & 13 & 30 & 59 \\
\hline Innmatur, slátur, svið, kæfa & 1 & 6 & 0 & 0 & 0 & 0 & 11 \\
\hline Fiskur, fiskafurðir og skeldýr alls & 26 & 29 & 0 & 0 & 19 & 48 & 87 \\
\hline Ferskur og frystur fiskur & 21 & 26 & 0 & 0 & 10 & 39 & 74 \\
\hline Fersk og fryst skeldýr & 3 & 8 & 0 & 0 & 0 & 1 & 24 \\
\hline Fuglakjöt & 32 & 32 & 0 & 0 & 27 & 49 & 94 \\
\hline Egg og eggjavörur & 14 & 17 & 0 & 0 & 8 & 22 & 52 \\
\hline Feitmeti: smjör, smjörlíki, olíur o.fl. & 14 & 11 & 3 & 6 & 11 & 17 & 31 \\
\hline Jurtaolíur, jurtafeiti & 2 & 3 & 0 & 0 & 1 & 2 & 7 \\
\hline Fiskolíur, lýsi & 1 & 3 & 0 & 0 & 0 & 0 & 10 \\
\hline Smjör, Smjörvi, Létt og laggott & 7 & 10 & 0 & 2 & 5 & 10 & 21 \\
\hline Smjörlíki, hert fita & 3 & 5 & 0 & 1 & 2 & 4 & 8 \\
\hline Hnetusmjör, fræsmjör & 1 & 2 & 0 & 0 & 0 & 0 & 5 \\
\hline Drykkir, nema mjólkurdrykkir alls & 1088 & 712 & 170 & 500 & 935 & 1568 & 2428 \\
\hline Vatn og sódavatn* & 653 & 654 & 0 & 38 & 488 & 1064 & 1842 \\
\hline Te, kaffi, kakóduft & 87 & 140 & 0 & 0 & 15 & 142 & 312 \\
\hline Gosdrykkir, svaladrykkir & 210 & 224 & 0 & 25 & 134 & 324 & 693 \\
\hline Hreinir safar, ávaxtasafar, berjasafar, grænmetissafar & 128 & 141 & 0 & 0 & 88 & 193 & 411 \\
\hline Íprótta- og orkudrykkir & 4 & 21 & 0 & 0 & 0 & 0 & 30 \\
\hline Poppkorn & 5 & 13 & 0 & 0 & 0 & 0 & 25 \\
\hline Flögur, skrúfur, kornstangir, annað snakk & 5 & 11 & 0 & 0 & 0 & 6 & 25 \\
\hline Sælgæti & 35 & 31 & 0 & 12 & 26 & 48 & 98 \\
\hline
\end{tabular}

*Vatnsneysla gæti verið vanskráð í matardagbókum. 
ar fyrir ófullnægjandi mataræði fremur en að gera ráð fyrir að allar konur sem eru yfir kjörpyngd séu í aukinni hættu. ${ }^{15}$

Mikilvægi fólats fyrir barnshafandi konur er vel pekkt og er hluti af klínískum leiðbeiningum um meðgönguvernd. ${ }^{25}$ Engu að síður benda niðurstöður rannsóknar okkar til pess að hluti kvenna fái ekki nægjanlegt fólat með fæðu og/eða bætiefnatöku. Minna en fjórðungur kvennanna fékk að minnsta kosti 500 g af fólati/ fólsýru úr mat og fæðubótarefnum á dag eins og ráðlagt er. ${ }^{14,16}$ Litla neyslu fólats úr fæði má rekja til lítillar neyslu á ávöxtum, grænmeti, hnetum, baunum, ertum og fræjum. Aukinn hlutur pessara fæðutegunda í fæði allra kvenna á barneignaaldri myndi stuðla að bættu almennu næringarástandi peirra og gæti hugsanlega skilað sér í færri fylgikvillum á meðgöngu. ${ }^{10-13,23,24}$ Lítil neysla D-vítamíns meðal hluta kvennanna í rannsókninni kom ekki á óvart og er í samræmi við niðurstöður annarra íslenskra rannsókna á mataræði landsmanna. ${ }^{5-8}$

Ekki er minnst sérstaklega á DHA og joð í bæklingnum Matur og meðganga ${ }^{26}$ eða klínískum leiðbeiningum um meðgönguvernd.$^{25}$ Pessi næringarefni gegna hlutverki við proska miðtaugakerfisins og hefur lítil neysla peirra á meðgöngu meðal annars verið tengd slakari útkomu á greindar- og proskaprófum barna. ${ }^{17-19,33}$ Pessi efni eiga pað sameiginlegt að pau er að finna í töluverðu magni í fiski (DHA í feitum fiski en joð í mögrum fiski). Litla neyslu DHA og joðs meðal hluta kvenna í rannsókninni má rekja til lítillar fiskneyslu peirra, sem pær betrumbæta ekki með notkun bætiefna á borð við lýsi (eða aðra fiskiolíu) eða ríflegri neyslu annarra matvæla sem innihalda joð. Mjólkurvörur eru góð uppspretta joðs í íslensku mataræði og benda fyrri rannsóknir til pess að barnshafandi konur sem ekki fylgja ráðleggingum um fiskneyslu (tvisvar sinnum í viku) og notkun mjólkurvara (tveir skammtar á dag) gætu verið í hættu á joðskorti. ${ }^{9}$

Styrkleiki rannsóknarinnar felst fyrst og fremst í mikilli nákvæmni við könnun á mataræði pátttakenda, par sem tekið var tillit til mismunandi skammtastærða. Vanskráning á neyslu er pó pekkt vandamál meðal einstaklinga yfir kjörpyngd og ekki hægt að útiloka að neysla hafi verið að einhverju leyti vanskráð í rannsókninni. ${ }^{34}$ Hins vegar reyndist ekki marktækur munur á orkuneyslu kvenna eftir pyngd peirra, auk pess sem konur sem voru í kjörpyngd fyrir meðgöngu höfðu pyngst meira við 20. viku meðgöngu heldur en konur sem töldust of feitar fyrir meðgöngu. Teljum við petta endurspegla nokkuð góða skráningu gagna, par sem orkupörf kvenna sem eru yfir kjörpyngd er að öllu jöfnu meiri en kvenna í kjörpyngd og pær pyngjast par af leiðandi minna við sömu orkuneyslu. Takmarkandi páttur í rannsókninni var að konurnar voru allar búsettar á höfuðborgarsvæðinu. Við teljum samt að niðurstöðurnar megi yfirfæra á önnur svæði landsins par sem niðurstöður Landskönnunar á mataræði 2010-2011 bentu til pess að ekki væri teljandi munur á mataræði kvenna á barneignaaldri í höfuðborginni og á landsbyggðinni. ${ }^{35}$ Eins er ekki hægt að útiloka að mataræði kvenna sem neituðu pátttöku í rannsókninni eða skiluðu ekki matardagbókum (alls 33\%) hafi verið frábrugðið pví sem hér var lýst.

Kallað er eftir markvissari skilaboðum til barnshafandi kvenna á Íslandi um hollustu fæðu og sérstöðu einstakra matvæla sem uppspretta mikilvægra næringarefna. Hluti barnshafandi kvenna í rannsókninni virðist ekki fá nóg af næringarefnum sem nauðsynleg eru fyrir eðlilegan vöxt og proska fósturs. Aukin gæði heildarmataræðis barnshafandi kvenna á Íslandi gætu skilað sér í færri fylgikvillum á meðgöngu og í fæðingu, sem og bættri heilsu móður og barns til langs tíma.

\section{Pakkir}

Höfundar pakka fósturgreiningardeild Landspítalans við aðstoð við öflun pátttakenda. Einnig Hólmfríði Porgeirsdóttur matvælaog næringarfræðingi hjá Embætti landlæknis og Ólafi Reykdal matvælafræðingi hjá MATÍS ohf. fyrir samstarf um gagnagrunna og forrit. Ívari Guðmundssyni hjá Hugsjá er pökkuð aðstoð við næringarefnaútreikninga.

Rannsóknasjóður Háskóla Íslands og Vísindasjóður Landspítala styrktu rannsóknina.

\section{Heimildir}

1. Barker DJ. The origins of the developmental origins theory. J Intern Med 2007; 261: 412-7.

2. Koletzko B, Brands B, Chourdakis M, Cramer S, Grote V, Hellmuth C, et al. The Power of Programming and the EarlyNutrition project: opportunities for health promotion by nutrition during the first thousand days of life and beyond. Ann Nutr Metab 2014; 64: 187-96.

3. Netting MJ, Middleton PF, Makrides M. Does maternal diet during pregnancy and lactation affect outcomes in offspring? A systematic review of food-based approaches. Nutrition 2014; 30: 1225-41.

4. Ramakrishnan U, Grant F, Goldenberg T, Zongrone A, Martorell R. Effect of women's nutrition before and during early pregnancy on maternal and infant outcomes: a systematic review. Paediatr Perinat Epidemiol 2012; 26 : 285-301.

5. Steingrímsdóttir L, Valgeirsdóttir H, Halldórsson PI, Gunnarsdóttir I, Gísladóttir E, Porgeirsdóttir $\mathrm{H}$, et al. Kannanir á mataræði og næringargildi fæounnar á Íslandi. Læknablaðið 2014; 100: 659-64.

6. Gunnarsdóttir I, Helgadóttir H, Pórisdóttir B, Pórsdottir I. Landskönnun á mataræði sex ára barna 2011-2012. Læknablaðið 2013; 99: 17-23.

7. Olafsdottir AS, Skuladottir GV, Thorsdottir I, Hauksson A, Steingrimsdottir L. Maternal diet in early and late pregnancy in relation to weight gain. Int J Obes (Lond) 2006; 30: $492-9$.
8. Thorsdottir I, Birgisdottir BE, Halldorsdottir S, Geirsson RT. Association of fish and fish liver oil intake in pregnancy with infant size at birth among women of normal weight before pregnancy in a fishing community. Am J Epidemiol 2004; 160: 460-5

9. Gunnarsdottir I, Gustavsdottir AG, Steingrimsdottir L, Maage A, Johannesson AJ, Thorsdottir I. Iodine status of pregnant women in a population changing from high to lower fish and milk consumption. Public Health Nutr 2013; 16: 325-9.

10. Willett W. Nutritional Epidemiology, third edition. Oxford University Press, New York 2012

11. Englund-Ögge L, Brantsæter AL, Sengpiel V, Haugen M, Birgisdottir BE, Myhre R, et al. Maternal dietary patterns and preterm delivery: results from large prospective cohort study. BMJ 2014; 348:g1446.

12. Brantsaeter AL, Haugen M, Samuelsen SO, Torjusen $\mathrm{H}$ Trogstad L, Alexander J, et al. A dietary pattern characterized by high intake of vegetables, fruits, and vegetable oils is associated with reduced risk of preeclampsia in nulliparous pregnant Norwegian women. J Nutr 2009; 139: $1162-8$.

13. Knudsen VK, Orozova-Bekkevold IM, Mikkelsen TB, Wolff S, Olsen SF. Major dietary patterns in pregnancy and fetal growth. Eur J Clin Nutr 2008; 62:463-70.

14. Nordic Nutrition Recommendations 2012. Integrating nutrition and physical activity. Nordic Council of Ministers 2014. norden.org/en/publications/publikationer/2014-002
15. Tryggvadottir EA, Medek H, Birgisdottir BE, Geirsson RT, Gunnarsdottir I. Association between healthy maternal dietary pattern and risk for gestational diabetes mellitus. Eur J Clin Nutr 2015 Sep 9.

16. Grundvöllur ráðlegginga um mataræði og ráðlagðir dagskammtar næringarefna. Embætti landlæknis, Reykjavík 2014.

17. Bath SC, Steer CD, Golding J, Emmett P, Rayman MP. Effect of inadequate iodine status in UK pregnant women on cognitive outcomes in their children: results from the Avon Longitudinal Study of Parents and Children (ALSPAC). Lancet 2013; 382: 331-7.

18. Zhou SJ, Anderson AJ, Gibson RA, Makrides M. Effect of iodine supplementation in pregnancy on child development and other clinical outcomes: a systematic review of randomized controlled trials. Am J Clin Nutr 2013; 98 : 1241-54.

19. Hyppönen E, Cavadino A, Williams D, Fraser A Vereczkey A, Fraser WD, et al. Vitamin D and pre-eclampsia: original data, systematic review and meta-analysis. Ann Nutr Metab 2013; 63:331-40.

20. Keenan K, Hipwell AE. Modulation of prenatal stress via docosahexaenoic acid supplementation: implications for child mental health. Nutr Rev 2015; 73: 166-74. 
21. Rodríguez-Bernal CL, Ramón R, Quiles J, Murcia M, Navarrete-Muñoz EM, Vioque J, Ballester F, Rebagliato M. Dietary intake in pregnant women in a Spanish Mediterranean area: as good as it is supposed to be? Public Health Nutr 2013; 16: 1379-89.

22. Haugen M, Brantsaeter AL, Alexander J, Meltzer HM. Dietary supplements contribute substantially to the total nutrient intake in pregnant Norwegian women. Ann Nutr Metab 2008; 52: 272-80.

23. Haugen M, Meltzer HM, Brantsaeter AL, Mikkelsen $T$, Osterdal ML, Alexander J, et al. Mediterranean-type diet and risk of preterm birth among women in the Norwegian Mother and Child Cohort Study (MoBa): a prospective cohort study. Acta Obstet Gynecol Scand 2008; 87:319-24.

24. Meltzer HM, Brantsæer AL, Nilsen RM, Magnus $\mathrm{P}$, Alexander J, Haugen M. Effect of dietary factors in pregnancy on risk of pregnancy complications: results from the Norwegian Mother and Child Cohort Study. Am J Clin Nutr 2011; 94 :1970S-1974S.
25. Meðgönguvernd heilbrigðra kvenna í eðlilegri meðgöngu. Klínískar leiðbeiningar. Landlæknisembættið og Heilsugæslan 2008.

26. Matur og meðganga. Fróðleikur fyrir konur á barneignaaldri. Lýðheilsustöð, Heilsugæslan og Matvælastofnun 2008

27. Cnattingius S, Villamor E, Johansson S, Edstedt Bonamy AK, Persson M, et al. Maternal obesity and risk of preterm delivery. JAMA 2013; 309: 2362-70.

28. Lau EY, Liu J, Archer E, McDonald SM, Liu J. Maternal weight gain in pregnancy and risk of obesity among offspring: a systematic review. J Obes 2014; 2014:524939.

29. Muktabhant B, Lawrie TA, Lumbiganon P, Laopaiboon M. Diet or exercise, or both, for preventing excessive weight gain in pregnancy. Cochr Datab Syst Rev 2015 6:CD007145.

30. O'Brien CM, Grivell RM, Dodd JM. Systematic review of antenatal dietary and lifestyle interventions in women with a normal body mass index. Acta Obstet Gynecol Scand. 2015 doi: 10.1111/aogs.12829.
31. Bain E1, Crane M, Tieu J, Han S, Crowther CA, Middleton $\mathrm{P}$. Diet and exercise interventions for preventing gestational diabetes mellitus. Cochr Datab Syst Rev 2015; 4:CD010443.

32. Poston L, Bell R, Croker H, Flynn AC, Godfrey KM, Goff L, et al. UPBEAT Trial Consortium. Effect of a behavioural intervention in obese pregnant women (the UPBEAT study): a multicentre, randomised controlled trial. Lancet Diabetes Endocrinol 2015; 3: 767-77.

33. Koletzko B1, Cetin I, Brenna JT. Dietary fat intakes for pregnant and lactating women. Br J Nutr 2007; 98:873-7.

34. Olafsdottir AS, Thorsdottir I, Gunnarsdottir I, Thorgeirsdottir H, Steingrimsdottir L. Comparison of women's diet assessed by FFQs and 24-hour recalls with and without underreporters: associations with biomarkers. Ann Nutr Metab 2006;50:450-60.

35. Guðjónsdóttir H, Halldórsson PI, Gunnarsdóttir I, Pórsdóttir I, Porgeirsdóttir H, Steingrímsdóttir L. Áhrif búsetu og menntunar á mataræði og líkamspyngdarstuðul kvenna og karla. Læknablaðið 2015; 101: 11-16.

\section{ENGLISH SUMMARY}

\section{Diet and nutrient intake of pregnant women in the capital area in Iceland}

Ingibjörg Gunnarsdóttir ${ }^{1,2}$, Ellen Alma Tryggvadóttir ${ }^{1,2}$, Bryndís Eva Birgisdóttir ${ }^{1,2}$, Pórhallur Ingi Halldórsson ${ }^{1,2}$, Helga Medek ${ }^{3}$, Reynir Tómas Geirsson ${ }^{3,4}$

Introduction: Nutrition in pregnancy may affect growth, development and health of the child in the short and long term. We aimed to assess diet and nutrient intake among pregnant women in the capital area and evaluate differences in dietary intake between women who were overweight/obese and normal weight before pregnancy.

Material and methods: Pregnant women aged $18-40$ years $(n=183)$ living in the capital area kept four day weighed food records to assess diet and nutrient intake in the $19^{\text {th }}-24^{\text {th }}$ week of pregnancy $(n=98$ with body mass index $(\mathrm{BMI})<25 \mathrm{~kg} / \mathrm{m}^{2} ; \mathrm{n}=46$ with $\mathrm{BMI} 25-29.9 \mathrm{~kg} / \mathrm{m}^{2}$ and $\mathrm{n}=39$ with $\mathrm{BMI} \geq 30 \mathrm{~kg} / \mathrm{m}^{2}$ ).

Results: Only $20 \%$ of the women consumed the minimum recommended $25 \mathrm{~g} /$ day of dietary fibers. The contribution of added sugar to the total energy intake was on average $12 \%$ (SD $\pm 5 \%$ ). About one-fo- urth appeared not to meet requirements for iodine, vitamin D and DHA (docosahexaenoic acid). No overconsumption of vitamins and minerals from food or supplements was observed. Higher median intake of milk and dairy products ( $346 \mathrm{~g} /$ day vs. $258 \mathrm{~g} /$ day, $\mathrm{p}<0.05)$, soft drinks (200 $\mathrm{g} /$ day vs. $122 \mathrm{~g} /$ day, $\mathrm{p}<0.05)$, as well as chips and popcorn $(13 \mathrm{~g} / \mathrm{day}$ vs. $0 \mathrm{~g} /$ day, $\mathrm{p}<0,05)$ was observed among women with $\mathrm{BMl} \geq 30 \mathrm{~kg} / \mathrm{m}^{2}$ compared with women of normal weight before pregnancy (BMI $<25 \mathrm{~kg}$ / $\left.\mathrm{m}^{2}\right)$.

Conclusion: Dietary habits and choices among women require enhanced consideration both before and in pregnancy, particularly among those who are obese. Sub-optimal consumption of iodine, vitamin $\mathrm{D}$ and $\mathrm{DHA}$, was seen among up to a quarter of the pregnant women.

${ }^{1}$ Unit for Nutrition Research, Landspitali University Hospital and University of Iceland, ${ }^{2}$ Faculty of Food Science and Nutrition, ${ }^{3}$ Department of Obstetrics and Gynecology, Women's Clinic, Landspitali University Hospital, ${ }^{4}$ Faculty of Medicine, School of Health Science, University of Iceland.

Key words: pregnancy, nutrition, dietary intake, essential fatty acids, iodine, vitamin D, folic acid.

Correspondence: Ingibjörg Gunnarsdóttir, ingigun@hi.is 